Jurnal Teknologi, 35(A) Dis. 2001: 47-56

(C) Universiti Teknologi Malaysia

\title{
THEORETICAL APPROACH ON THE GROWTH RATE OF SOLIDIFIED METAL INTERFACE
}

\author{
D. PRAYITNO ${ }^{1}$, E. HAMZAH ${ }^{2}$, M.Z.M. GHAZALI ${ }^{3}$ \& A.J. CLEGG ${ }^{4}$
}

\begin{abstract}
When nucleation is completed, the solidification process will continue with nucleus growth. Increasing the growth rate will reduce the grain size of metal. Thus the study on the casting parameters which have an effect on the growth rate should be carried out in order to improve the mechanical properties of the metal. This work thus proposes an equation of growth rate of solidified metal interface in the molten state which is poured from a moving tundish into an inclined mould. The proposed equation can be practically applied and the parameters can be experimentally determined.

Keywords: Solidification; casting; nucleation; grain growth

Abstrak. Apabila penukleusan telah lengkap, proses pemejalan seterusnya melibatkan pertumbuhan nukleus. Pertambahan kadar pertumbuhan akan mengecilkan saiz bijian logam. Oleh itu, kajian ke atas paramater-parameter tuangan yang memberi kesan ke atas kadar pertumbuhan perlu dilakukan bagi memperbaiki sifat mekanik logam. Kertas kerja ini dengan itu mencadangkan suatu persamaan kadar pertumbuhan antara muka logam pepejal dalam keadaan lebur yang dituangkan daripada suatu tundish bergerak ke dalam suatu acuan condong. Persamaan yang dicadangkan boleh digunakan secara praktik dan parameter-parameternya boleh ditentukan secara ujikaji.
\end{abstract}

Kata kunci: Pemejalan logam; tuangan; penukleusan; pertumbuhan bijian

\subsection{INTRODUCTION}

Grain refining has been regarded as one of the most effective ways to upgrade metals since it can improve many mechanical properties, such as strength, toughness, ductility and fatigue strength. The grain-refining methods that are carried out in the melting and casting stage are generally more direct and efficient in obtaining a fine-grain product than those applied in the subsequent processing of ingots or billets. This is due to the fact that the former can reduce the homogenization time and save the thermomechanical or heat-treatment efforts for refining the grain structure.

The principles of grain refining during casting are: (a) an increase in cooling rate, (b) an addition of a grain refiner and (c) an application of an external force. Increas-

\footnotetext{
$1 \& 2$ Faculty of Mechanical Engineering

3 Faculty of Civil Engineering, Universiti Teknologi Malaysia

4 Loughborough University, UK.
} 
ing cooling rate can accelerate the nucleation rate and thus results in smaller grain size. A chill block may be employed on the basis of this principle. A grain-refining agent can induce a number of crystal nuclei near the solid-liquid interface and thus prohibit the growth of columnar grains. Turbulent flow can be generated by the application of a mechanical or electromagnetic force to the melt. The turbulent flow can, as a result, enhance crystal multiplication by breaking and remelting the dendrite.

Once a nucleus is formed, it will continue to grow. The growth rate of a solidified metal interface is also important to consider for reducing the grain size of as-cast structures, since increasing the growth rate reduces the tip radius of dendrites and dendrite arm spacing. The concept of constitutional supercooling is probably one of the most significant factors leading to a theoretical explanation of alloy solidification [1]. This theory was mathematically described by Tiller et al., [2] and more recently applied to the understanding of weld solidification by Savage et al., [3]. In these investigations it was shown that solidification parameters i.e. alloy solute content, thermal gradient in the liquid $(G)$ and the growth rate of the solidifying interface $(R)$ were found to influence the resultant solidification structure. In the absence of constitutional supercooling (which for a given alloy system is indicative of steep thermal gradient and/or low growth rate), a planar interface would prevail. If the thermal gradient or growth rates were such that constitutional supercooling increases (low ratio of $G / R$ ), the interface would become unstable and break down into one of the several dendritic-growth modes.

Many researchers [4-8] have studied and investigated the effect of growth rate on the individual solidification structure. Important parameters such as tip radius of curvature and initial secondary dendrite arm spacing were predicted as functions of growth rate. Burden and Hunt $[4,5]$ developed a theory for dendritic growth based on measurement of the tip temperature of cell and dendrites under unidirectional solidification. The undercooling at the dendrite tip is given by an expression of the form as shown in equation (1) at high thermal gradient, $G$ and low velocities of growth rate $R$, and $D$ is the coefficient diffusion constant,

$$
\Delta T=\frac{G D}{R}
$$

However at high velocities the undercooling $\Delta T \propto R^{n}$ where $n$ is between 0.4 and 0.5 . They also suggested a correlation between the radius of curvature $(r)$ and the growth rate $(R)$ which is as follows;

$$
r=\left\{\frac{20 D}{\left[-m R(1-k) C_{\infty}\right]}\right\}^{\frac{1}{2}}
$$


where $\quad m=$ liquidus slope (K/wt \%)

$k=$ ratio solid composition and liquid composition

$C_{\infty}=$ composition at infinity (wt \%)

$G=$ thermal gradient in liquid $(\mathrm{K} / \mathrm{m})$

$\Delta T=$ undercooing $(\mathrm{K})$

Trivedi [6] proposed the theory of dendritic growth of binary alloys. At low growth rates the radius of curvature $(r)$ can be expressed as follows;

$$
r=\left(\frac{2 D}{R}\right)\left(\frac{1-k}{k}\right)\left(\frac{G D}{R \Delta T_{0}}\right)\left[1-\frac{G D}{R \Delta T_{0}}\right]^{-1}
$$

where $k$ is the ratio of solid composition and liquid composition $\left(C_{s} / C_{l}\right) \cdot \Delta \mathrm{T}_{0}$ is the liquidus to solidus range temperature. Thus, when $k<1$ finite radius of dendrite is obtained only when $\frac{G D}{R \Delta T_{0}}<1$. Also for a planar interface condition, $r \rightarrow \infty$ (radius of dendrite close to infinite), is obtained when $\frac{G D}{R \Delta T_{0}} \rightarrow 1$.

At high velocities, since the thermal gradient effect are negligible, the radius of curvature $(r)$ can be expressed as;

$$
r^{2}=\frac{2 \gamma D L}{\Delta S \Delta T_{0} R}
$$

where $\quad L \sim 10$ is a constant

$$
\begin{aligned}
\Delta S & =\text { entropy }\left(\mathrm{erg} / \mathrm{cm}^{3}{ }^{\circ} \mathrm{C}\right) \\
\gamma & =\text { solid/liquid interfacial free energy }\left(\mathrm{erg} / \mathrm{cm}^{2}\right)
\end{aligned}
$$

Thus, as in the case of the free dendrite growth $R r^{2}=$ constant for a given system under constrained growth condition when the temperature gradient effects are negligible.

Esaka and Kurz [7] proposed an equation to obtain the relationship between the initial secondary dendrite arm spacing $\left(\lambda_{2}\right)$ and the growth rate $(R)$ which is as follows:

$$
\lambda_{2} R^{0.51}=8.15 \times 10^{-5}\left(\mathrm{~cm}^{1.51} \mathrm{~s}^{-0.51}\right)
$$

Kurz and Fisher [8] proposed an equation for the prediction of tip radius of a dendrite $(r)$ as a function of growth rate $(R)$; 


$$
r=2 \pi \sqrt{\frac{D \Gamma}{R k \Delta T_{0}}}
$$

where $\Gamma=$ Gibbs - Thompson Coefficient $(\mathrm{Km})$

Based on the welding metal structure, Porter [9] proposed an equation to suggest that the growth rate of an interface $(R)$ is equal to the welding speed $(v)$.

$$
R=v \cos \theta
$$

where $\theta$ is the angle between growth rate direction and welding direction. Since the welding speed is constant, the growth rate has to vary considerably depending on the position at the liquidus. It thus follows that the growth rate at the weld centre line behind the moving heat source $\left(\theta \sim 0^{\circ}\right)$ grows fastest, while growth rate at the edge of the weld $\left(\theta \sim 90^{\circ}\right)$ grows slowest.

According to Lancester [10] the solidification velocity $(R)$ of the weld pool is equal to the welding speed, $v$, multiplied by the sine of the angle $\varphi$ between the tangent to the weld pool boundary and the welding direction;

$$
R=v \sin \varphi
$$

Based on the equations proposed by these researchers, the present work proposed an equation on the growth rate of the solidified interface from molten metal poured from a moving tundish in an inclined mould which can be practically applied to design a new near shape casting machine.

\subsection{THEORETICAL BASIS OF THE PROPOSED GROWTH RATE EQUATION}

Since the molten metal solidifies in the metal mould, heat extracted through the mould is the heat of fusion of the solidifying metal. Thus the heat flux balance is

$$
h=\frac{\rho \Delta H_{f} R}{\left(T_{m}-T_{s}\right)}
$$

where $\quad T_{m}=$ melting temperature of metal $(\mathrm{K})$

$T_{s}=$ solid temperature of solidified metal $(\mathrm{K})$

$\rho=\operatorname{density}\left(\mathrm{kg} / \mathrm{m}^{3}\right)$

$\Delta H_{f}=$ heat fusion of metal $(\mathrm{cal} / \mathrm{kg})$

$R=$ crystal growth rate (assumed as a vector) $(\mathrm{m} / \mathrm{s})$

The assumptions for equation (9) include: (a) the molten is in the Newtonian conditions, (b) the heat from the molten metal is extracted by the mould with perpendicular direction to the mould wall, (c) the growth direction is parallel and opposite of the heat flow direction, (d) quantity of molten metal is small, and (e) the heat 
transfer on the melt substrate interface dominates and that negligible temperature gradient exists in the melt. The melt shows a characteristic of a laminar flow [11].

The growth rate, $R$, is assumed to be a vector which can be modified into $R_{x}$ due to the molten metal flowing (assumed as laminar flow) with velocity, $v$, which is also a vector [12];

$$
R_{x}^{2}=R^{2}+v^{2}
$$

\subsection{VELOCITY DISTRIBUTION ON THE MOLTEN METAL IN AN INCLINED MOULD}

In the present proposal the molten metal was poured from a moving tundish into a $\mathrm{D}$ groove of an inclined mould in order to obtain finer grain sizes. The velocity distribution of molten metal in the experimental set up is based on the momentum balance $[13,14]$. The equation of momentum balance for a steady flow is as follows;

$$
\begin{gathered}
\text { (rate of } \\
\text { omentum in })
\end{gathered}-\begin{gathered}
\text { (rate of } \\
\text { momentum out })
\end{gathered}+\begin{gathered}
\text { (sum of forces } \\
\text { acting on system) }
\end{gathered}=0
$$

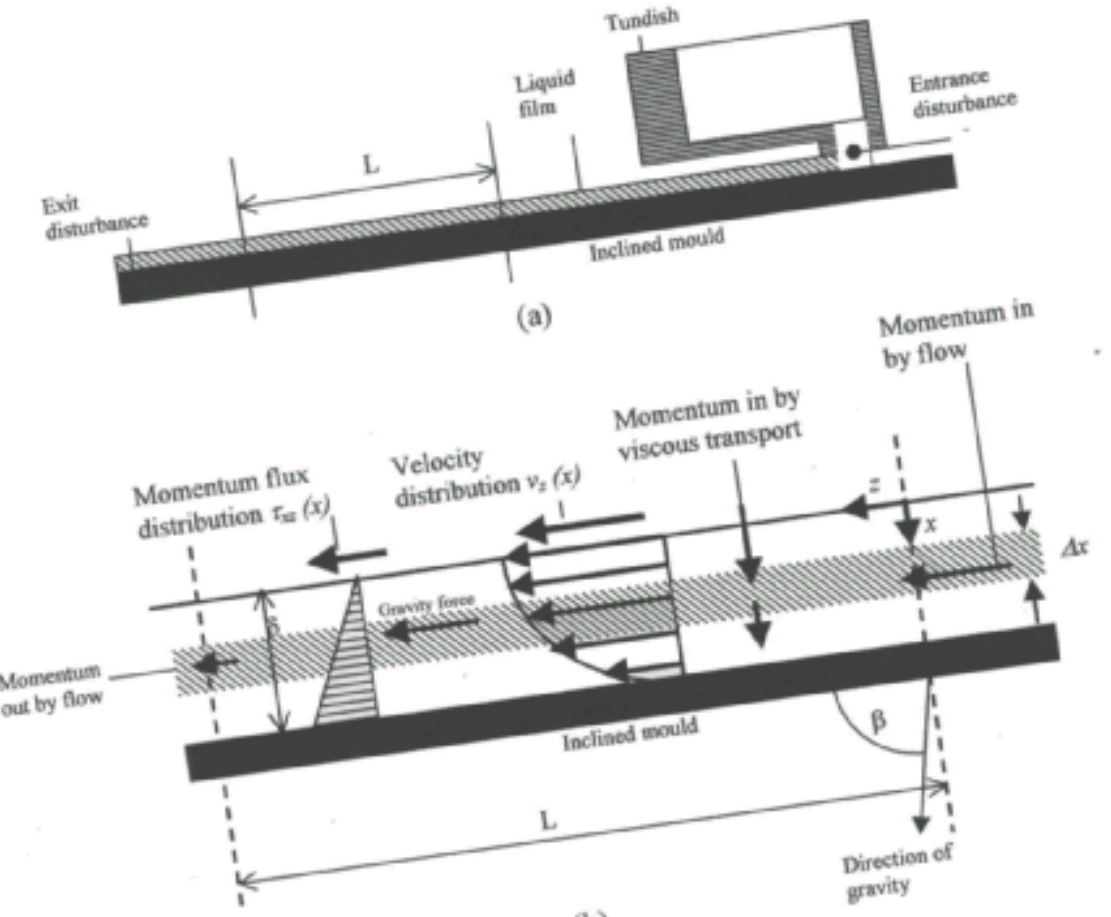

(b)

Figure 1 Velocity Distribution of Molten Metal in the D-shaped Inclined Mould. (a) Molten Metal Flows out From Tundish into the D-shaped Inclined Mould (b) Parts of Momentum Balance 
Now consider the flow of liquid at a steady state along the $\mathrm{D}$ groove as shown in Figure 1. The liquid is at a constant temperature, and therefore its density and viscosity are constant. Furthermore, only that portion of the $\mathrm{D}$ groove we consider where the entry and exit of the fluid to the D-Groove sufficiently removed so as not to influence the velocity, $v_{z}$. In this situation, $v_{z}$ is not a function of $z$ but obviously a function of $x$. Figure 1 also depicts the unit volume as a "shell" with a thickness $\Delta x$ and length $L$, radius of the shell is $\delta$. The important terms considered to solve equation (3.1) is given as follows;

Rate of momentum in across $\mathrm{D}$ groove surface at $x$ (momentum transport due to viscosity)

$$
\left.\left(\left(\frac{2 \pi x}{2}\right) L\right)\left(\tau_{x z}\right)\right|_{x}
$$

Rate of momentum out across $\mathrm{D}$ groove surface at $x+\Delta x$ (due to viscosity)

$$
\left.\left(\left(\frac{2 \pi x}{2}\right) L\right)\left(\tau_{x z}\right)\right|_{x+\Delta x}
$$

Rate of momentum in across $\mathrm{D}$ groove surface at $z=0$ (due to fluid motion)

$$
\left.\left(\left(\frac{2 \pi x}{2}\right) \Delta x v_{z}\right)\left(\rho v_{z}\right)\right|_{z=0}
$$

Rate of momentum out across $\mathrm{D}$ groove surface at $z=L$ (due to fluid motion)

$$
\left.\left(\left(\frac{2 \pi x}{2}\right) \Delta x v_{z}\right)\left(\rho v_{z}\right)\right|_{z=L}
$$

Gravity force acting on fluid

$$
\left(\left(\frac{2 \pi x}{2}\right) L \Delta x\right)(\rho g \times \cos \beta)
$$

In this particular problem, the pressure is assumed to be equal throughout the liquid. Also note that all terms in the list including the first two are $z$-directed forces. Figure 1 (b) shows that momentum-in by viscous transports is $x$ directed, but if we think of interpreting $\tau_{x z}$ in an alternative way, namely, as shear stress we certainly realize that we are dealing with a $z$-directed force.

When all these terms are substituted into the momentum balance, we get;

$$
\begin{gathered}
\left.\left(\frac{2 \pi x}{2}\right) L \tau_{x z}\right|_{x}-\left.\left(\frac{2 \pi x}{2}\right) L \tau_{x z}\right|_{x+\Delta x}+\left.\left(\frac{2 \pi x}{2}\right) \Delta x \rho v_{z}^{2}\right|_{z=0}-\left.\left(\frac{2 \pi x}{2}\right) \Delta x \rho v_{z}^{2}\right|_{z=\ell} \\
+\left(\frac{2 \pi x}{2}\right) L \Delta x \rho g \cos \beta=0
\end{gathered}
$$

Since we are restricted to that part of the inclined mould which does not feel the effect of the exit and entrance, $v_{z}$ is independent of $z$. Therefore, the third and fourth 
terms cancel one another out. Equation (12) is now divided by $\left(\frac{2 \pi}{2}\right) L \Delta x$ and, if $\Delta x$ is allowed to be infinitely small, we obtain

$$
\lim _{\Delta x \rightarrow 0} \frac{\left.\tau_{x z}\right|_{x+\Delta x}-\left.\tau_{x z}\right|_{x}}{\Delta x}=\rho g \cos \beta
$$

We have now recognized the definition of the first derivative of $\tau_{x z}$ with respect to $x$, and have thus developed the differential equation pertinent to our system;

$$
\frac{d \tau_{x z}}{d x}=\rho g \cos \beta
$$

this equation is integrated to yield

$$
\tau_{x z}=\rho g x \cos \beta+C_{1}
$$

Equation (15) describes the momentum flux (or alternatively the shear-stress distribution), but contains an integration constant $C_{1}$. This constant is evaluated by recognizing that the shear stress in the liquid is very nearly zero at a liquid-gas interface. In other words the gas phase in this instance offers little resistance to liquid flow which results in a realistic boundary condition: Boundary Condition 1 at $x=0$, $\tau_{x z}=0$. Substitution of this boundary condition into equation (15) requires that $C_{1}=0$; hence the momentum flux is

$$
\tau_{x z}=\rho g x \cos \beta
$$

If the fluid is newtonian, then we know that the momentum flux is related to velocity gradient according to

where $\eta=$ viscosity $\left(\mathrm{Ns} \mathrm{m}^{-2}\right)$

$$
\tau_{x z}=-\eta \frac{d v_{z}}{d x}
$$

Substituting this expression for $\tau_{x z}$ in equation (16) gives the distribution of the velocity gradient:

$$
\frac{d v_{z}}{d x}=-\frac{\rho g \cos \beta}{2 \eta} x
$$

integrating Equation (18), we have

$$
v_{z}=-\frac{\rho g \cos \beta}{\eta} x^{2}+C_{2}
$$


Another integration constant has evolved which is evaluated by examining the other boundary condition, namely, that at the liquid-solid interface the fluid clings to the wall that is boundary condition 2. At $x=\delta, v_{z}=0$. Substituting this boundary condition into equation (19), we determine the constant of integration; $C_{2}=\left(\frac{\rho g \cos \beta}{2 \eta}\right) \delta^{2}$. Therefore the velocity distribution is:

$$
v_{z}=\frac{\rho g \delta^{2} \cos \beta}{2 \eta}\left[1-\left(\frac{x}{\delta}\right)^{2}\right]
$$

and is parabolic. Once the velocity profile has been found a maximum velocity, $v_{z}^{\max }$, is that velocity at $x=0$,

$$
v_{z}^{\max }=\frac{\rho g \delta^{2} \cos \beta}{2 \eta}
$$

The foregoing analytical results are valid only when the liquid is in laminar flow (straight streamlines).

There is an assumption that the maximum velocity $v_{z}^{\max }$ is equal to the tundish speed, $v_{\text {tundish }}[15,16]$. Thus equation (20) could be replaced as follows:

$$
v_{z}=v_{\text {tundish }}\left[1-\left(\frac{x}{\delta}\right)^{2}\right]
$$

\subsection{GROWTH RATE EQUATION}

Since the velocity of molten metal in the D-groove of inclined mould is distributed as velocity distribution $\left(v_{z}\right)$, The molten velocity $(v)$ in the equation $(10)$ could be replaced by $v_{z}$. Thus the growth rate of the solidified metal can be expressed as follows;

$$
R_{x}^{2}=R^{2}+v_{z}^{2}
$$

When equation (9) and (22) are substituted into equation (23), an equation for growth rate as shown in Figure 2 can be obtained as follows;

$$
R_{x}^{2}=\left[\frac{h\left(T_{m}-T_{s}\right)}{\rho \Delta H_{f}}\right]^{2}+\left(v_{\text {tundish }}\left[1-\left(\frac{x}{\delta}\right)^{2}\right]\right)^{2}
$$


where $R_{x}$ is growth rate of solidified interface in a flowing molten metal. This is schematically shown in Figure 2.
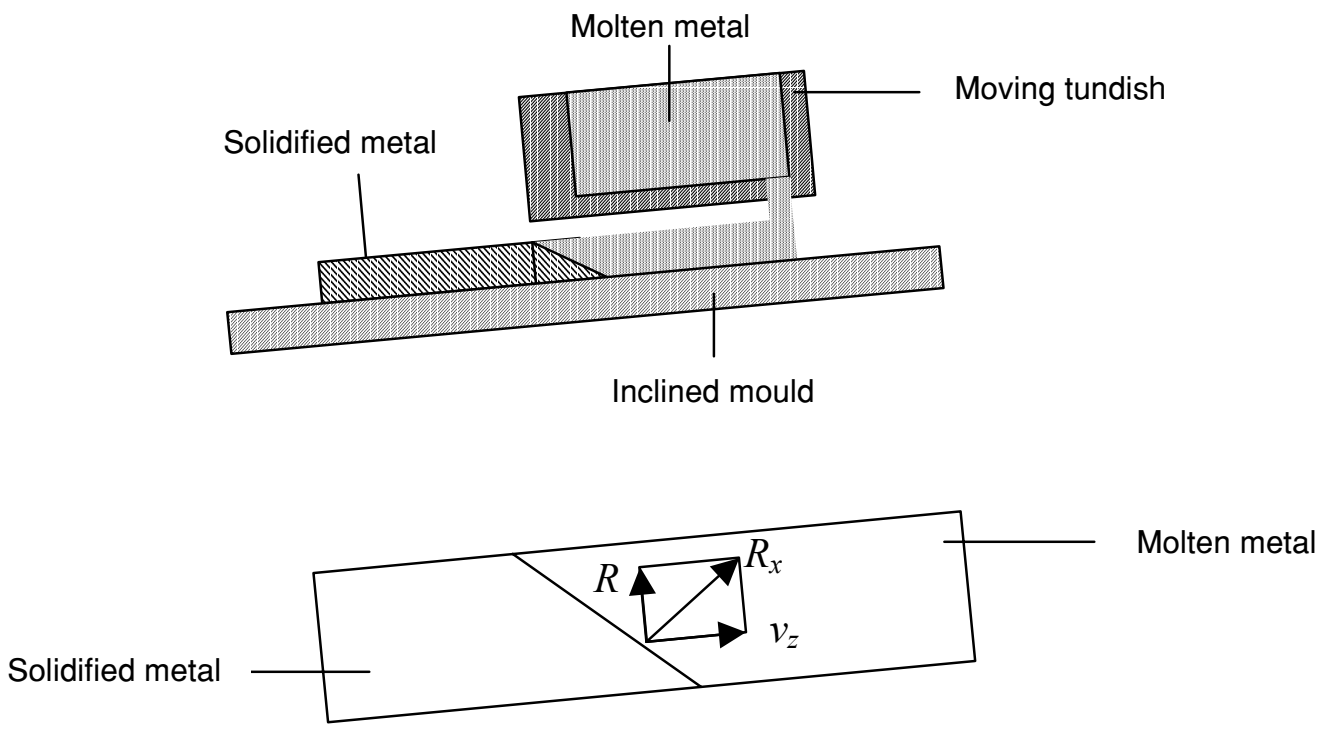

Figure 2 Growth rate of solidified metal interface in the D-shaped inclined mould

Based on the three dimensional heat flow on welding process [17] and thermal boundary layer theory $[18,19]$, the molten metal which is directly in contact with the base metal has a temperature value close to the base metal temperature or mould temperature, where as the centre line surface of molten metal has a temperature value close to its melting temperature. Based on these arguments it can be said that the solid temperature $\left(T_{s}\right)$ in equation (24) depends on its location in the molten metal. Since the location is near to the mould wall, $T_{s}$ is relatively equal to the mould temperature and the $T_{s}$ is close to the melting temperature at the centre line of surface of the molten metal. Thus all the parameters in the proposed equation can be determined experimentally and this equation may be used to design a new near shape casting machine which may improve the mechanical properties of any ferrous or non-ferrous metals.

\subsection{CONCLUSION}

An equation of growth rate of solidification metal has been proposed which can be practically applied and experimentally determined in order to design a new near shape casting machine for ferrous and non-ferrous metals. 


\section{ACKNOWLEDGEMENT}

The authors would like to acknowledge The Malaysian Ministry of Science, Technology and Environment for funding this project (IRPA Project No: 03-02-06-0140).

\section{REFERENCES}

[1] Rutter, J. W., and B. Chalmers. 1953. A Prismatic Substructure Formed During Solidification of Metals. Canadian Journal of Physics. 3

[2] Tiller, W. A., K. A. Jackson, J. W. Rutter, and B. Chalmers. 1953. The Redistribution of Solute Atoms During Solidification of Metals, Acta Metallurgica. 1

[3] Savage, W. F., C. D. Lundin, and A. H. Aronson. 1965. Weld Metal Solidification Mechanics. Welding Journal. 44 (4): 175-181.

[4] Burden, M. H and J. D. Hunt. 1974. Cellular and Dendritic Growth I. Journal of Crystal Growth. 22: 99108.

[5] Burden, M. H., and J. D. Hunt. 1974. Cellular and Dendritic Growth II. Journal of Crystal Growth. 22: 109-116.

[6] Trivedi 1980. Theory of Dendrite Growth During the Directional Solidification of Binary Alloys. Journal of Crystal Growth. 49: 219-232

[7] Esaka, H., and W. Kurz. 1985. Columnar Dendritic Growth: Experiment on Tip Growth. Journal of Crystal Growth. 72: 578-584

[8] Kurz, W., and D. J. Fisher. 1981. Dendrite Growth at The Limit of Stability: Tip Radius and Spacing. Acta Metallurgical. 29: 11-20.

[9] Porter, D. A., and K. E. Easterling. 1981. Phase Transformations in Metals and Alloys. Chapmann and Hall: London.

[10] Lancester, J. F. 1980. Metallurgy of Welding. George Allen \& Unwin: London

[11] Prayitno, D., E. Hamzah, and M. Z. M. Ghazali. 1998. A Study on Crystal Growth Rate on Small Metal Casting. Proceeding Malaysian Science and Technology Congress ‘98: 261-269

[12] Prayitno, D., E. Hamzah, and M. Z. M. Ghazali. 1999. A Proposed Model: Near Shape Casting for Reinforcing Steel Bar. Proceeding Seminar Construction, Material and Environmental Technology, Universiti Teknologi Malaysia: 143-150. 